\title{
The viral aetiology of influenza-like illnesses in Kampala and Entebbe, Uganda, 2008
}

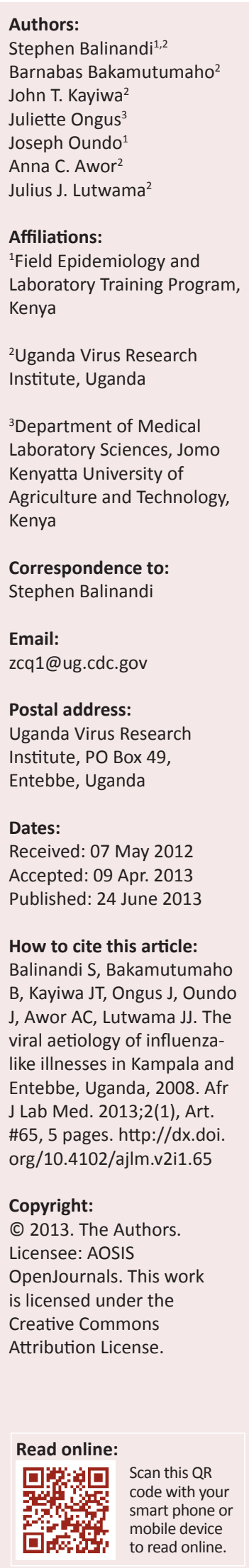

Background: As the threat of zoonoses and the emergence of pandemic-prone respiratory viruses increases, there is a need to establish baseline information on the incidence of endemic pathogens in countries worldwide.

Objectives: To investigate the presence of viruses associated with influenza-like illnesses (ILI) in Uganda.

Methods: A cross-sectional study was conducted in which nasopharyngeal swab specimens were collected from patients diagnosed with ILI in Kampala and Entebbe between 14 August 2008 - 15 December 2008. A multiplex polymerase chain reaction assay for detecting 12 respiratory viruses was used.

Results: A total of 369 patients (52.3\% females) was enrolled; the median age was 6 years (range $1-70)$. One or more respiratory viruses were detected in $172(46.6 \%)$ cases and their prevalence were influenza A virus (19.2\%), adenovirus (8.7\%), human rhinovirus A $(7.9 \%)$, coronavirus OC43 $(4.3 \%)$, parainfluenza virus $1(2.7 \%)$, parainfluenza virus $3(2.7 \%)$, influenza B virus $(2.2 \%)$, respiratory syncytial virus B $(2.2 \%)$, human metapneumovirus $(1.4 \%)$, respiratory syncytial virus A (1.1\%), parainfluenza virus $2(0.5 \%)$ and coronavirus $229 \mathrm{E}(0.5 \%)$. There were $24(14.0 \%)$ mixed infections.

Conclusions: This study identified some of the respiratory viruses associated with ILI in Uganda. The circulation of some of the viruses was previously unknown in the study population. These results are useful in order to guide future surveillance and case management strategies involving respiratory illnesses in Uganda.

\section{Introduction}

Globally, influenza-like illnesses (ILI), also known as acute respiratory illnesses, are common causes of morbidity and mortality in both developed and developing countries. ${ }^{1,2}$ In temperate climates, ILI is reported throughout the year amongst hospital patients with a marked increase in cases recorded during winter periods. There is also evidence of sporadic background activity of ILI transmission throughout the year amongst communities in tropical climates, with a slight increase in cases during the rainy season. ${ }^{3,4,5}$ However, little is known about the aetiologic agents of ILI in some developing countries, making it a challenge to plan and implement effective patient management and disease prevention and control efforts. ${ }^{6,7}$

As surveillance and monitoring programmes for ILI scale up in many countries, primarily triggered by the increased threat of zoonosis and the emergence of pandemic-prone respiratory viruses, there is a need to identify and document the incidence of endemic and circulating pathogens. This information is important for differential diagnosis, outbreak investigations, trend analysis, early recognition of emerging and re-emerging viruses and implementation of specific public health interventions such as mass vaccination campaigns. In Uganda, a tropical country lying along the equator, surveillance for influenza was started in July 2007. By June 2008 , influenza viruses were confirmed in only $12 \%$ of patients presenting with ILI at health facilities, implying that the aetiologies in the remaining $88 \%$ were unknown. ${ }^{8}$ There are a few studies in Uganda that have identified influenza viruses, respiratory syncytial viruses, parainfluenza viruses, coxsackieviruses and echoviruses as being causative agents of ILI - but these studies were conducted during the 1970s.9,10,11 More recent results from other countries including Senegal, Cote d'Ivoire, Kenya and Madagascar have shown that these viruses are in circulation together with newly-discovered viruses such as coronaviruses, bocaviruses and polyomaviruses..$^{12,13,14,15,16}$ In the current study, we identify the respiratory viruses that are associated with ILI patients seeking healthcare in Kampala city and Entebbe town, both located in the central region of Uganda. 


\section{Research methods and design Study locations and target population}

This study was carried out under the national protocol for the routine surveillance of human influenza in Uganda. Patients of all ages presenting with ILI at the sentinel surveillance sites for influenza at Kiswa Health Centre in the Ugandan capital Kampala and Entebbe Hospital in Entebbe town were enrolled into this cross-sectional study between August and December 2008. These two study sites are separated from each other by approximately $35 \mathrm{~km}$.

Using a World Health Organization (WHO)-modified criterion as used by others, ${ }^{17,18,19}$ an ILI case was defined as any individual presenting with fever $\left(\geq 38^{\circ} \mathrm{C}\right)$ and any two of the following clinical signs: cough, sore throat, myalgia and headache. A maximum of five eligible cases was enrolled on each day at each of the study sites. Patient demographic characteristics and clinical history were recorded on a standardised clinical form. The presentation of other related symptoms, such as shortness of breath, conjunctivitis, diarrhoea and vomiting, was also recorded. This information was obtained from the caregiver if the patient was unable to speak or was a child.

\section{Laboratory testing}

All the laboratory testing was carried out at the National Influenza Centre (NIC) located at Uganda Virus Research Institute, Entebbe, Uganda. This laboratory is the national reference centre for human influenza surveillance in Uganda and participates routinely in the WHO External Quality Assessment Panel Programme for influenza viruses. A nasopharyngeal swab (Pur-Wraps ${ }^{\circledR}$, Puritan Medical Products Company LLC, Maine, USA) was collected from each study participant. Specimens collected at health centres were placed immediately in $500 \mu 1$ of viral transport media (Dulbecco's Modified Eagle's Medium ${ }^{\circledR}$, Highveld Biological Ltd, Lyndhurst, South Africa; supplemented with $0.5 \%$ serum albumin, $100 \mathrm{U} / \mathrm{ml}$ of Penicillin and $100 \mathrm{U} / \mathrm{ml}$ of Streptomycin), stored in liquid nitrogen and transported to the NIC for further analysis.

A commercially-available multiplex PCR kit (Seeplex ${ }^{\circledR}$ RV Detection; Seegene Inc, Rockville, MD, USA) for the detection of adenovirus, influenza A and B viruses, respiratory syncytial viruses $A$ and $B$, human metapneumovirus, parainfluenza viruses 1, 2 and 3, rhinovirus A, and coronaviruses 229E and OC43 was used. This kit has been used elsewhere to identify respiratory viruses in similar specimens. ${ }^{20,21}$ The assay was performed according to the manufacturer's instructions. Briefly, total nucleic acids (both ribonucleic acid [RNA] and deoxyribonucleic acid [DNA]) were extracted from the collected specimens (Viral Gene-Spin ${ }^{\mathrm{TM}}$, iNtRON Biotechnology, Gyeonggi-do, Korea) and target sequences present in the extracts were then reverse transcribed (for the RNA form) and amplified in two separate assays of multiplex polymerase chain reaction (PCR; $\mathrm{mPCR}$ ) using virus-specific kit primers. One assay contained primers for adenovirus (amplicon size 534 bp), human metapneumovirus (469 bp), coronavirus 229E (375 bp), parainfluenza virus 1 (324 bp), parainfluenza virus 2 (264 bp), and parainfluenza virus 3 (219 bp), whilst the other mPCR assay had primer sets for influenza A virus (513 bp), influenza B virus (455 bp), respiratory syncytial virus B (391 bp), rhinovirus A (337 bp), respiratory syncytial virus A (273 bp) and coronavirus OC43 (231 bp). The amplified products were observed using agarose gel electrophoresis. Specimens that had matching bands corresponding to the expected amplicon sizes for each type of virus relative to the molecular weight marker $\left(\right.$ Seeplex $\left.{ }^{\circledR}\right)$ were scored as positive for that virus. Kit positive and negative controls were also included in every assay run. An internal positive control (Seeplex ${ }^{\circledR}$ ) was also included to evaluate the amplification efficiency of each tested specimen.

\section{Ethical considerations}

As these data were collected from patients as part of routine healthcare delivery and were anonymous, the Uganda Ministry of Health guidelines did not require ethical review. Informed (verbal) consent was obtained from each study participant or caregiver.

\section{Trustworthiness}

This study was conducted following the national guidelines for Influenza surveillance as established by the Ugandan Ministry of Health. Thus, all the study participants were identified and recruited by trained healthcare workers using a modified WHO case definition for ILI. In addition, all laboratory procedures were performed in a WHO collaborating reference laboratory following the kit manufacturer's instructions. Both the specimen collection and laboratory testing methods have been used elsewhere in similar studies. . $^{17,18,19,20,21}$

\section{Results}

\section{Demographic and clinical characteristics of study participants}

Between August and December 2008, a total of 369 study participants presenting with ILI at the two study centres were recruited. Of these, 286 (77.5\%) participants were from Entebbe Hospital and 83 (22.5\%) participants were from Kiswa Health Centre (Table 1). Both genders were represented in almost equal proportions (52.3\% females and $47.7 \%$ males) and the median age was 6 years (range: 1-70). Over half of the study participants $(61.5 \%)$ were aged 10 years or less, and had low or no form of education (74.5\%).

All patients were seen at the outpatient departments of the two study sites and none required hospital admission at the time of enrolment. Apart from fever, the most common clinical symptoms were cough $(98.4 \%)$, shortness of breath $(43.1 \%)$ and headache $(29.0 \%)$. Only $3.8 \%(n=14)$ of the study participants reported the presence of a chronic condition or illness such as active tuberculosis, chronic cough and chest pain. Almost all of the participants (94.5\%) reported to the clinic within three days (range: 1-31) of the onset of symptoms. 
TABLE 1: Demographic characteristics of patients with influenza-like illness at Kiswa Health Center and Entebbe Hospital, Uganda, between August 2008 and December 2008.

\begin{tabular}{|c|c|c|c|c|}
\hline \multirow[t]{2}{*}{ Characteristic } & \multirow[t]{2}{*}{ Variable } & Entebbe Hospital & \multirow{2}{*}{$\begin{array}{c}\text { Kiswa Health Center } \\
n=83\end{array}$} & \multirow{2}{*}{$\begin{array}{c}\text { Overall (\%) } \\
n=369\end{array}$} \\
\hline & & $n=\mathbf{2 8 6}$ & & \\
\hline \multirow[t]{2}{*}{ Gender } & Male & 133 & 43 & $176(47.7)$ \\
\hline & Female & 153 & 40 & $193(52.3)$ \\
\hline Median Age (Years) & - & 7 & 3 & 6 \\
\hline \multirow[t]{5}{*}{ Age-groups (Years) } & $<1$ & 37 & 9 & $46(12.5)$ \\
\hline & $1-5$ & 86 & 43 & $129(35.0)$ \\
\hline & $11-20$ & 40 & 8 & $48(13.0)$ \\
\hline & $21-30$ & 54 & 5 & $59(16.0)$ \\
\hline & $31+$ & 32 & 3 & $35(9.5)$ \\
\hline \multirow[t]{3}{*}{ Maximum level of education completed } & None/Pre-primary & 205 & 70 & $275(74.5)$ \\
\hline & Primary & 57 & 7 & $64(17.3)$ \\
\hline & Secondary & 21 & 6 & $27(7.3)$ \\
\hline \multirow[t]{4}{*}{ Occupation } & Child/Student & 186 & 71 & $257(69.6)$ \\
\hline & Unemployed & 75 & 4 & $79(21.4)$ \\
\hline & Self-employed & 20 & 7 & $27(7.3)$ \\
\hline & Private/Government-employed & 5 & 1 & $6(1.6)$ \\
\hline
\end{tabular}

Source: Authors' own construction

\section{Frequencies of detected viral aetiologies}

Out of 369 swab specimens collected and analysed, 172 (46.6\%) were positive for one or more respiratory agents. The most frequently-detected respiratory virus amongst all study participants was influenza A $(n=71,19.2 \%)$. Others were adenovirus $(n=32,8.7 \%)$, rhinovirus A $(n=29,7.9 \%)$ and coronavirus OC43 $(n=16,4.3 \%)$. The least-detected respiratory viruses were parainfluenza virus $2(n=2,0.5 \%)$ and coronavirus 229E ( $n=2,0.5 \%)$ (Table 2). Approximately $63.0 \%$ of all viral detections, including all the parainfluenza viruses (1, 2 and 3 ) and $78.1 \%$ of adenovirus and $75.0 \%$ of coronavirus OC43, were detected from study participants who were aged 10 years or less. Only Rhinovirus A and all influenza viruses were detected across all ages.

\section{Mixed viral infections}

Of the 172 that tested positive for respiratory agents, there were $24(14.0 \%)$ cases with mixed infections of two or three viruses. No patient was infected with more than three viruses. Twenty-one cases were infected with two viruses, with the most frequent mixture being adenovirus and influenza A virus $(n=5)$. Other frequent viral mixtures were adenovirus and rhinovirus A $(n=3)$ and influenza A virus and coronavirus OC43 $(n=3)$ (Table 3). Adenovirus was present in $62.5 \%$ $(n=15)$ of mixed infections which was almost a half $(46.9 \%)$ of all detections for this virus. Respiratory syncytial virus B was the only aetiology that was not detected in a mixed infection.

\section{Discussion}

This study identified viral aetiologies in $46.6 \%$ of all ILI cases at two health facilities in Kampala and Entebbe, Uganda, a prevalence level similar to that reported in other studies. ${ }^{22,23,24}$ The identified aetiologies include influenza A and B virus, adenovirus, rhinovirus A, coronavirus OC43
TABLE 2: Frequency and prevalence of respiratory viruses amongst patients presenting with influenza-like illness at Kiswa Health Center and Entebbe Hospital, Uganda, between August 2008 and December 2008; $n=369$.

\begin{tabular}{lcc}
\hline Detected respiratory virus & Frequency & Prevalence $(95 \% \mathrm{Cl})$ \\
\hline Influenza A virus & 71 & $19.2(15.7-24.0)$ \\
Adenovirus & 32 & $8.7(6.1-12.1)$ \\
Rhinovirus A & 29 & $7.9(5.4-11.2)$ \\
Coronavirus OC43 & 16 & $4.3(2.6-7.1)$ \\
Parainfluenza virus 1 & 10 & $2.7(1.4-5.1)$ \\
Parainfluenza virus 3 & 10 & $2.7(1.4-5.1)$ \\
Influenza B virus & 8 & $2.2(1.0-4.4)$ \\
Respiratory syncytial virus B & 8 & $2.2(1.0-4.4)$ \\
Human metapneumovirus & 5 & $1.4(0.5-3.3)$ \\
Respiratory syncytial virus A & 4 & $1.1(0.3-2.9)$ \\
Parainfluenza virus 2 & 2 & $0.5(0.1-2.2)$ \\
Coronavirus 229E & 2 & $0.5(0.1-2.2)$ \\
\hline
\end{tabular}

Source: Authors' own construction

TABLE 3: Mixed infections amongst patients presenting with influenza-like illness attending Kiswa Health Center and Entebbe Hospital, Uganda, between August 2008 and December 2008; $n=24$.

\begin{tabular}{lc}
\hline Mixed viral aetiologies & Frequency (n) \\
\hline Adenovirus and influenza A virus & 5 \\
Adenovirus and rhinovirus A & 3 \\
Influenza A virus and coronavirus OC43 & 3 \\
Adenovirus and parainfluenza virus 1 & 2 \\
Influenza A virus and rhinovirus A & 2 \\
Human metapneumovirus and rhinovirus A & 1 \\
Adenovirus and human metapneumovirus & 1 \\
Parainfluenza virus 1 and parainfluenza virus 3 & 1 \\
Respiratory syncytial virus A and parainfluenza virus 2 & 1 \\
Adenovirus and influenza virus B & 1 \\
$\begin{array}{l}\text { Influenza A virus and coronavirus 229E } \\
\text { Triple aetiologies, Parainfluenza virus 1, adenovirus } \\
\text { and coronavirus OC43 }\end{array}$ & 1 \\
$\begin{array}{l}\text { Triple aetiologies, Parainfluenza virus 3, adenovirus } \\
\text { and coronavirus OC43 }\end{array}$ & 1 \\
$\begin{array}{l}\text { Triple aetiologies, Parainfluenza virus 1, adenovirus } \\
\text { and rhinovirus A }\end{array}$ & 1 \\
\hline
\end{tabular}

Source: Authors' own construction 
and 229E, parainfluenza virus 1, 2 and 3, respiratory syncytial virus $\mathrm{A}$ and $\mathrm{B}$ and human metapneumovirus. A number of these aetiologies have only recently been identified and their circulation in Uganda was unknown previously. These include human metapneumovirus, whose discovery as a causative agent for ILI has been recognised only in the last decade. ${ }^{25}$

Most of the detected viruses, including parainfluenza virus 1, 2 and 3, influenza B virus, adenovirus, human metapneumovirus and coronaviruses OC43 and 229E, were circulating at prevalence levels that were, in general, similar to those found elsewhere. ${ }^{12,14,26,27}$ Influenza A virus was detected in $19.2 \%$ of ILI cases, which was higher than the $12 \%$ prevalence level that was known to exist from previous observations in the same population. ${ }^{8}$ The higher prevalence observed for this virus could be attributed to the timing of this study which was conducted when rainfall is highest in Uganda. It is probable that an outbreak associated with this virus was ongoing during the study period as observed previously. $4,5,6$ Conversely, rhinovirus A was detected at $7.9 \%$ which is lower than the $10 \%-25 \%$ prevalence levels found in other ILI surveillance studies within sub-Saharan tropics. ${ }^{13,14,16,28}$ In the same studies, the prevalence of respiratory syncytial viruses A and B ranged between 5\% - 21\% which is higher than our $3.3 \%$ total prevalence for the same viruses. The low prevalence levels observed for these viruses could also be associated with their seasonality in the study population - a variable that could not be established with our current crosssectional data. Also, our ILI case definition was focused more on influenza surveillance and could have been restrictive with regard to the signs and symptoms of other ILI aetiologies. ${ }^{29,30}$

Mixed infections amongst all cases that tested positive for respiratory agents accounted for $14.0 \%$ of the findings, with the majority being double infections. The prevalence of mixed infections ranging from $4.5 \%-70 \%$ are reported from other studies, depending on the geographical location of the study area, the diagnostic method used or the general degree of illness in the study population. ${ }^{24,31,32,33}$ The high prevalence of mixed influenza A virus and adenovirus infections during a low circulation cycle of respiratory syncytial virus infection has previously been suggested. ${ }^{34}$ In our study, the number of mixed infections $(n=24)$ was not adequate to allow statistical analysis; a more comprehensive study is necessary in order to determine the associations and interactions between these viruses as well as the related clinical outcomes.

\section{Limitations of the study}

This study had a number of limitations. Firstly, the number of viruses detectable by the multiplex PCR kit was limited to 12; it is possible that other respiratory viruses were circulating in the study population but were not identified. Secondly, only nasopharyngeal swabs were collected, possibly missing viruses in the lower respiratory tract. Thirdly, the study period was limited to four months and epidemiological aspects associated with these viruses such as seasonality could not be established.

\section{Conclusion}

We have shown the viral aetiologies of some of the ILI in the study population that were not caused by influenza viruses. This information is vital for use in the future to guide policymaking on respiratory disease surveillance and case management in Uganda.

\section{Acknowledgements}

We would like to thank all the staff at Entebbe Hospital and Kiswa Health Centre, especially Roselyn Mutonyi, Janet Aliru, Lucy Wanyenze, Grace Kaija and Molly Busingye, who in addition to their routine hospital work, accepted the task of taking on the extra responsibility of collecting data for this study. We also thank Robert Downing, Njenga M. Kariuki and Benjamin D. Moser for their technical support. The study participants' enrolment in this study is highly appreciated. We are also indebted to the Centers for Disease Control and Prevention, Atlanta, USA who provided funding for this study through the African Field Epidemiology Network and the Kenya Field Epidemiology and Laboratory Training Programme.

\section{Competing interests}

The authors declare that they have no financial or personal relationship(s) which may have inappropriately influenced them in writing this article.

\section{Authors' contributions}

S.B. (FELTP and Uganda Virus Research Institute), B.B. (Uganda Virus Research Institute), J.O. (Jomo Kenyatta University), J.O. (FELTP) and J.J.L. (Uganda Virus Research Institute) conceived and provided technical design of the study; S.B., B.B. and J.T.K. (Uganda Virus Research Institute) performed both clinical and laboratory data collection; S.B. and A.C.A. (Uganda Virus Research Institute) performed computer data entry and analysis; and S.B., J.O., J.O. and J.J.L. wrote the article.

\section{References}

1. World Health Organization. The global burden of disease: 2004 update. [page on Internet]. [c2009] [cited 2011 May 2]. Available from: http://whqlibdoc.who.int/ publications/2008/9789241563710_eng.pdf

2. Williams BG, Gouws E, Boschi-Pinto C, et al. Estimates of world-wide distribution of child deaths from acute respiratory infections. Lancet Infect Dis. 2002;2(1):25-32. http://dx.doi.org/10.1016/S1473-3099(01)00170-0

3. Chew FT, Doraisingham $S$, Ling $A E$, et al. Seasonal trends of viral respiratory tract infections in the tropics. Epidemiol Infect. 1998;121(1):121-128. http://dx.doi. org/10.1017/S0950268898008905, PMid:9747763, PMCid:2809482

4. Moura FE, Perdigão AC, and Siqueira MM. Seasonality of influenza in the tropics: a distinct pattern in northeastern Brazil. Am J Trop Med Hyg. 2009;81(1):180-183.
PMid:19556586

5. Dosseh A, Ndiaye K, Spiegel A, et al. Epidemiological and virological influenza survey in Dakar, Senegal: 1996-1998. Am J Trop Med Hyg. 2000;62(5):639-643. PMid:11289677

6. Rudan I, Lawn J, Cousens S, et al. Gaps in policy-relevant information on burden of disease in children: a systematic review. Lancet. 2005;365(9476):2031-2040. http://dx.doi.org/10.1016/S0140-6736(05)66697-4

7. Gessner BD, Shindo N, Briand S. Seasonal influenza epidemiology in sub-Saharan Africa: a systematic review. Lancet Infect Dis. 2011;11(3):223-235. http://dx.doi. org/10.1016/S1473-3099(11)70008-1 
8. Lutwama JJ, Bakamutumaho B, Kayiwa JT, et al. Clinic- and hospital-based sentine influenza surveillance, Uganda 2007-2010. J Infect Dis. 2012;206 Suppl 1:S87-93. http://dx.doi.org/10.1093/infdis/jis578, PMid:23169978

9. Fayinka OA, Balayan MS, Kirya GB, et al. An outbreak of influenza B in a closed community school in Uganda. East Afr Med J. 1977; 54(1):6-8. PMid:852457

10. Montefiore D, Drozdov SG, Kafuko GW, et al. Influenza A2-HongKong-68 virus in Uganda. Trop Geogr Med. 1970;22(4):452-458. PMid:5497379

11. Sobĕslavský O, Sebikari SRK, Harland PSEG, et al. The viral etiology of acute respiratory infections in children in Uganda. Bull World Health Organ. 1977;55(5): 625-631. PMid:201391, PMCid:2366699

12. Berkley JA, Munywoki $P$, Ngama $M$, et al. Viral etiology of severe pneumonia among Kenyan infants and children. JAMA. 2010;303(20):2051-2057. http://dx.doi. org/10.1001/jama.2010.675, PMid:20501927, PMCid:2968755

13. Niang MN, Diop OM, Sarr FD, et al. Viral etiology of respiratory infections in children under 5 years old living in tropical rural areas of Senegal: The EVIRA project. J Med Virol. 2010;82(5):866-872. http://dx.doi.org/10.1002/jmv.21665, PMid:20336732

14. Razanajatovo NH, Richard V, Hoffmann J, et al. Viral etiology of influenza-like illnesses in Antananarivo, Madagascar, July 2008 to June 2009. PLoS One. 2011;6(3):e17579. http://dx.doi.org/10.1371/journal.pone.0017579, PMid:21390235, PMCid:3048401

15. Hammitt LL, Kazungu S, Morpeth SC, et al. A preliminary study of pneumonia etiology among hospitalized children in Kenya. Clin Infect Dis. 2012;54 Suppl 2 S190-S199. http://dx.doi.org/10.1093/cid/cir1071, PMid:22403235, PMCid:3297554

16. Kadjo HA, Ekaza E, Coulibaly D, et al. Sentinel surveillance for influenza and other respiratory viruses in Cote d'Ivoire, 2003-2010. Influenza Other Resp Viruses. 2012;7(3):296-303. http://dx.doi.org/10.1111/j.1750-2659.2012.00389.x PMid:22863403

17. Boivin G, Hardy I, Tellier G, et al. Predicting influenza infections during epidemics with use of a clinical case definition. Clin.Infect.Dis. 2000;31(5):1166-1169. http:// dx.doi.org/10.1086/317425, PMid:11073747

18. Monto AS, Gravenstein S, Elliott M, et al. Clinical signs and symptoms predicting influenza infection. Arch Intern Med. 2000;160(21):3243-3247. http://dx.doi. org/10.1001/archinte.160.21.3243, PMid:11088084

19. Zambon M, Hays J, Webster A, et al. Diagnosis of influenza in the community: relationship of clinical diagnosis to confirmed virological, serologic, or molecula detection of influenza. Arch Intern Med. 2001;161(17):2116-2122. http://dx.doi. org/10.1001/archinte.161.17.2116, PMid:11570941

20. Drews SJ, Blair J, Lombos E, et al. Use of the Seeplex RV Detection kit for surveillance of respiratory viral outbreaks in Toronto, Ontario, Canada. Ann Clin Lab Sci. 2008; 38(4):376-379. PMid:18988931

21. Yoo SJ, Kuak EY, Shin BM. Detection of 12 respiratory viruses with two-set multiplex reverse transcriptase-PCR assay using a dual priming oligonucleotide system. Korean J Lab Med. 2007;27(6):420-427. http://dx.doi.org/10.3343/kjlm.2007.27.6.420 PMid:18160832
22. Ahmed JA, Katz MA, Auko E, et al. Epidemiology of respiratory viral infections in two long-term refugee camps in Kenya, 2007-2010. BMC Infect Dis. 2012;12:7. http:// long-term refugee camps in Kenya, 2007-2010. BMC Infect Dis. 2012;12:7.

23. Sung RY, Chan PK, Tsen T, et al. Identification of viral and atypical bacterial pathogens in children hospitalized with acute respiratory infections in Hong Kong by multiplex PCR assays. J Med Virol. 2009;81(1):153-159. http://dx.doi.org/10.1002/jmv.21364, PMid:19031443

24. Thomazelli LM, Vieira S, Leal AL, et al. Surveillance of eight respiratory viruses in clinical samples of pediatric patients in southeast Brazil JPediatr (Rio J.). 2007;83(5): 422-428.

25. van den Hoogen BG, de Jong JC, Groen J, et al. A newly discovered human pneumovirus isolated from young children with respiratory tract disease. Nat Med. 2001;7(6): 719-724. http://dx.doi.org/10.1038/89098, PMid:11385510

26. van Gageldonk-Lafeber AB, Heijnen ML, Bartelds Al, et al. A case-control study of acute respiratory tract infection in general practice patients in The Netherlands. Clin Infect Dis. 2005;41(4):490-497. http://dx.doi.org/10.1086/431982, PMid:16028157

27. Wong S, Pabbaraju K, Pang XL, et al. Detection of a broad range of human adenoviruses in respiratory tract samples using a sensitive multiplex real-time PCR assay. J Med Virol. 2008;80(5):856-865. http://dx.doi.org/10.1002/jmv.21136, PMid:18360899

28. O'Callaghan-Gordo C, Bassat Q, Morais L, et al. Etiology and epidemiology of viral pneumonia among hospitalized children in rural Mozambique: a malaria endemic area with high prevalence of human immunodeficiency virus. Pediatr Infect Dis J. 2011;30(1):39-44. http://dx.doi.org/10.1097/INF.0b013e3181f232fe, PMid:20805786

29. Casalegno JS, Frobert E, Escuret $\mathrm{V}$, et al. Beyond the influenza-like illness surveillance: The need for real-time virological data. Euro Surveill. 2011;16(1):1-2.

30. Walsh EE, Peterson DR, Falsey AR. Is clinical recognition of respiratory syncytial virus infection in hospitalized elderly and high-risk adults possible? J Infect Dis. 2007;195(7):1046-1051. http://dx.doi.org/10.1086/511986, PMid:17330796

31. Lina B, Valette $M$, Foray $S$, et al. Surveillance of community-acquired viral infections due to respiratory viruses in Rhone-Alpes (France) during winter 1994 to 1995. Clin Microbiol. 1996;34(12):3007-3011. PMid:8940439, PMCid:229450

32. Brunstein JD, Cline CL, McKinney S, et al. Evidence from multiplex molecular assays for complex multipathogen interactions in acute respiratory infections. J Clin Microbiol. 2008;46(1):97-102. http://dx.doi.org/10.1128/JCM.01117-07, PMid:17977985, PMCid:2224244

33. Greensill J, McNamara PS, Dove W, et al. Human metapneumovirus in severe respiratory syncytial virus bronchiolitis. Emerg Infect Dis. 2003;9(3):372-375. http:// dx.doi.org/10.3201/eid0903.020289, PMid:12643835, PMCid:2958536

34. Forgie IM, Campbell H, Lloyd-Evans $\mathrm{N}$, et al. Etiology of acute lower respiratory tract infections in children in a rural community in The Gambia. Pediatr Infect Dis J. 1992;11(6):466-473. http://dx.doi.org/10.1097/00006454-199206000-00009, PMid:1608684 